\title{
Cross-Curricular Analysis of Picture Books in the Fifth Grade of Primary School: A Case Study
}

Janja Batič ${ }^{\star 1}$ ANd Petra Lebar KaC ${ }^{2}$

$\approx$ Picture books discussed with pupils in primary school are considered multimodal texts, as they combine at least two communication codes (verbal and visual). A discussion involving picture books will normally be included in Slovenian language lessons, with pupils focussing mostly on the text. The visual aspect, which equally carries a message, is often neglected. The objective of the present case study that was conducted among fifth-grade primary school pupils in the 2018/19 school year was to explore how a cross-curricular approach to planning and executing the lessons in the Slovenian language and visual art can help pupils learn about the characteristics of the picture book as a multimodal text. We conducted a set of didactic activities entitled Getting to know the picture book, introducing selected picture books to pupils as part of their Slovenian language classes, which resulted in them developing their receptive skills while observing and defining the structure of the texts. In visual art classes, the pupils learned about the visual features of the picture book. As a productive response to the picture book discussed, the pupils were instructed to complete the following tasks: design a cover for their own picture book, design endpapers, illustrate their own poem, and produce their own leporello. The survey involved 21 pupils, a generalist teacher, and a researcher in art didactics. The case study was completed in five weeks. The data were obtained by means of initial and final testing, questionnaires for pupils, and participant observation.

Keywords: art education, the Slovenian language, cross-curricular teaching, multimodal literacy, picture book

1 *Corresponding Author. Faculty of Education, University of Maribor, Slovenia; janja.batic@um.si.

2 Primary school Janka Padežnika Maribor, Slovenia. 


\section{Medpredmetna obravnava slikanice v petem razredu osnovne šole (študija primera)}

Janja Batič in Petra Lebar KaC

$\approx$ Slikanice, ki jih obravnavamo z učenci v osnovni šoli, spadajo med multimodalna besedila, saj imajo najmanj dva koda sporočanja (literarnega in likovnega). Obravnava slikanic običajno poteka pri pouku slovenščine, pri čemer je pozornost učencev usmerjena predvsem na besedilo. Pri tem je likovni del, ki je v slikanici enakovreden nosilec sporočila, pogosto zanemarjen. Namen študije primera, ki smo jo izvedli v petem razredu osnovne šole v šolskem letu 2019/20, je bil raziskati, kako lahko s pomočjo medpredmetnega načrtovanja in izvajanja pouka slovenščine in likovne umetnosti učencem omogočimo, da spoznajo značilnosti slikanice kot multimodalnega besedila. V raziskavi nas je zanimalo, kako medpredmetno zastavljene naloge, ki vključujejo cilje s področja slovenščine in likovne umetnosti, vplivajo na učenčevo dojemanje multimodalnega besedila. Izvedli smo didaktični sklop Spoznavam slikanico, v katerem so učenci ob izbranih slikanicah pri slovenščini razvijali recepcijske zmožnosti in opazovali ter določali členjenost besedil. Pri likovni umetnosti pa so s pomočjo slikanice spoznavali likovne zakonitosti, likovne tehnike in oblikovne značilnosti slikanice. Produktivni odziv na prebrano slikanico je vseboval naslednje dejavnosti: oblikovanje naslovnice za lastno slikanico, oblikovanje veznih listov, ilustracija avtorske pesmi in oblikovanje avtorskega leporela. $\mathrm{V}$ raziskavo smo vključili 21 učencev petega razreda osnovne šole, učiteljico razrednega pouka in raziskovalko s področja didaktike likovne umetnosti. Študija primera je trajala pet tednov. Podatke smo pridobivali $\mathrm{z}$ začetnim in $\mathrm{s}$ končnim testiranjem, $\mathrm{z}$ vprašalniki za učence, intervjujem $\mathrm{z}$ učiteljico in $\mathrm{z}$ opazovanjem $\mathrm{z}$ udeležbo.

Ključne besede: likovna vzgoja (likovna umetnost), slovenščina, medpredmetno poučevanje, multimodalna pismenost, slikanica 


\section{Introduction}

Picture books are, by definition, multimodal ensembles combining two communication codes: the visual and the verbal codes (Batič, 2017; Batič \& Haramija, 2015; Haramija \& Batič, 2013). Serafini (2014) introduces the term "multimodal continuum «, comprising a range of diverse multimodal ensembles: textually dominant ensembles (e.g., essays, lectures, legal documents), composite structures (e.g., picture books, magazines, webpages, graphic novels), and visually dominant ensembles (e.g., photography, painting, sculpture, picture books without text). Notwithstanding this, picture books are generally discussed in Slovenian classes, focusing on textual analysis with illustrations considered to be an addition to the text. Serafini (2014, p. 17) notes: »A focus on written language to the exclusion of visual images may be problematic given the multimodal nature of modern communication «. Cappello et al. (2019, p. 208) note: "Often learners are limited by a print-centric curriculum in schools despite the many options for demonstrating and making meaning ", which means that understanding and teaching literacy must be broadened to encompass both visual and multimodal literacies. Multimodal literacy is developed through a variety of multimodal practices in almost all subject areas. The results of a survey of teachers' views of multimodal practices and $\mathrm{K}-12$ classrooms showed that teachers positively acknowledge the potential of multimodal practices, but at the same time, they also have some concerns (i.e., time for planning and implementation of multimodal lessons) (Yi \& Choi, 2015). The question that arises first is that of teachers' visual and multimodal literacy, as it is impossible to expect teachers to help children develop competences that they do not possess themselves. Visual literacy is the ability to interpret visual images and create messages with images. Eilam (2012, pp. 3-4) expands the notion by saying that teachers' visual literacy is "not only the learned ability to interpret visual messages, and even to create them, but the ability to locate relevant visual materials and evaluate their suitability for communicating, learning, and teaching purposes«. Visual literacy is one of the conditions for multimodal literacy, which is the ability to decode the message of multimodal ensembles, that is, the ability to discern the meaning created by a combination of different communication modes (Jewitt, 2008; Serafini, 2014). For this reason, picture book discussion is an excellent opportunity for children to develop their visual and multimodal literacies in school.

One question that arises is what model should a teacher use in discussing picture books and in which school subject it should be included. There are several models used for discussing picture books (Doonan, 1993; Serafini, 2014). What they all have in common is that they introduce children to various 
communication codes and relevant terminology, and teach them to decode the meaning from image and text (multimodal analysis) as well as enabling the construction of one's own multimodal message. All the above characteristics imply this is an interdisciplinary model that can be implemented only through cross-curricular teaching. Pavlič Škerjanc (2010) introduces three types of curriculum: a traditional curriculum (isolated teaching, hardly any integration within the subject), enriched traditional curriculum (occasional interdisciplinary connections), and integrative curriculum (searching for answers to a common problem or question). Picture book discussion tends to search for answers to a common problem or question, making one wonder what message a picture book is trying to convey. To understand the overall message, however, one needs to combine the messages incorporated in both the text (the objectives of Slovenian language teaching) and the image (the objectives of art education). The question of what message a picture book is conveying can only be answered once we intertwine both spheres. A survey completed in 2017, which included 443 preschool and classroom teachers, showed that while picture books were frequently present in the teaching process, there was unused potential in terms of developing children's visual and multimodal literacy (Batič, 2019). The question is how to construct a model of picture book discussion that will support an interdisciplinary concept, development, and use of vocabulary from the fine arts while developing multimodal literacy.

\section{Method}

\section{Research problem and research questions}

The objective of our survey was to identify, through cross-curricular planning and delivery of Slovenian and art education lessons, the means to construct a model of interdisciplinary picture book discussion that will help children develop multimodal literacy. We based our survey on the observation that visual literacy is a precondition for the development of one's multimodal literacy, which is, in turn, is related to the development of viewing skills which comprise »observing, interpreting what one sees, probing and reflecting on first and second thoughts, considering alternative meanings", (Yenawine, 2013, p. 12). Therefore, it is vital that in a cross-curricular discussion of a multimodal text, pupils are allowed enough time for active observation, which will then serve as their basis for further steps towards gaining visual and multimodal literacy. We created a case study showcasing a specific example, comprehensively and systematically (Sagadin, 1991; Vogrinc, 2008). 
We posed the following questions:

1. How do pupils evaluate individual activities within an interdisciplinary module?

2. What are pupils' attitudes to a teaching module delivered in an interdisciplinary manner?

3. How do pupils perceive the message of a multimodal text before and after the delivery of an interdisciplinary module?

\section{Sample and participants}

We used a convenience sample, as our survey was conducted among fifth graders in a primary school with which we frequently collaborate on prospective teachers' training. The survey included all fifth graders $(n=21)$ but not all were present during all units due to occasional legitimate absences. The class include 13 boys and eight girls, of which two were gifted pupils, three pupils were of the Roma nationality, and two were special needs pupils. One pupil suffered from severe scotopic sensitivity syndrome and needed some adjustments to the working materials; his handouts were printed on green paper, which best suited his condition.

The survey included a generalist teacher with 11 years of experience, who delivered the content related to Slovenian classes, and a faculty researcher with 17 years of experience, who delivered the content related to art education classes. Both teachers were in class at the same time, complementing each other's work.

\section{Instruments}

The interdisciplinary module (Getting to know the picture book) is an attempt at constructing a model for an interdisciplinary approach to picture book discussion, which incorporates gradual terminology acquisition (cover, inside cover, endpaper, text, illustration, illustrator), text reading, active observation of the illustrations, multimodal analysis (identifying the meanings of both communication codes), and producing a multimodal text.

Before and after the delivery of the interdisciplinary module (Getting to know the picture book), we tested the pupils' ability to comprehend the message in a multimodal ensemble. The pupils were shown the cover of Slovenian Fairy Tales (and One German) in Comics by Matjaž Schmidt and were asked to identify the message it conveyed. They had ten minutes to observe the cover and write down their answers. Before and after each learning unit, the pupils were given a questionnaire, the first testing their prior knowledge and the second 
examining their response to the learning unit delivered. The answers provided were transcribed, and the data were grouped into categories (Mesec, 1998).

Data acquisition also included participant observation. After each unit, the teachers delivering the lessons evaluated the learning unit completed in view of the goals set and the pupils' responses to the activities performed.

\section{Results}

\section{Delivery of the interdisciplinary module entitled Getting to know the picture book}

\section{The first unit of the interdisciplinary module}

The first unit of the module comprised three lessons. Regarding the Slovenian language, the pupils developed their reception skills, explored sensory imagining of literary characters and space, and identified the use of non-literary elements in the text, trying to relate these to the personalities and other traits of the literary characters. They further collected the information regarding the course of events and the information needed to wrap up the development of events not included in the text. Regarding art education, the pupils learned some terms related to two-dimensional design (colour tone, familiar colours, contrast colours), and produced a collage that helped them develop their understanding of the spatial arrangement of various shapes on a surface.

The pupils were initially given a short questionnaire with a series of openended questions to test their knowledge of the term "picture book«. The questionnaire was completed by 18 pupils. We discovered that the majority of pupils associated picture books with pictures. Also, we concluded that over half of the pupils were unable to name the last picture book they had read. What attracts the pupils most in a picture book is the abundance of pictures and the scarcity of text.

The pupils were first introduced to the Slovenian translation of the picture book by Mélanie Watt, entitled Vilibald (Chester, 2014). They were initially motivated by being instructed to identify the author of the picture book merely by observing the book cover. The picture book is entirely designed as a dialogue between the author and her cat, who keeps correcting her text and illustrations with a red pen. After reading the picture book, the pupils were encouraged to discuss the illustrations, focussing on two different artistic expressions (Mélanie's paintings and Vilibald's drawings). Using a worksheet provided, they described the literary characters (Mélanie, Vilibald, mouse, dog), distinguishing between the information they derived from the text and that which was provided by the illustrations. 
Mélanie Watt is simultaneously telling a story and illustrating it in the picture book; she appears in a photograph and a simple drawing (drawn by her cat Vilibald). When asked about what they learned about this particular character from the text and from the illustrations, the pupils provided various answers, which are listed in Table 1 below.

Table 1

Answers to the question: What did you learn about Mélanie Watt based on the text and what based on the illustrations?

\begin{tabular}{|c|c|c|}
\hline \multirow{10}{*}{$\begin{array}{l}\text { Answers to the question: } \\
\text { What did you learn } \\
\text { about Mélanie Watt } \\
\text { based on the text and } \\
\text { what based on the } \\
\text { illustrations? }\end{array}$} & Based on the text & Based on the illustrations \\
\hline & She is angry with Vilibald (4 pupils) & Angry or very angry (5 pupils) \\
\hline & She is telling a story (3 pupils) & No answer (4 pupils) \\
\hline & $\begin{array}{l}\text { She wanted to write her own } \\
\text { story ( } 2 \text { pupils) }\end{array}$ & $\begin{array}{l}\text { She is happy because she is smil- } \\
\text { ing in the picture ( } 4 \text { pupils) }\end{array}$ \\
\hline & She is kind (2 pupils) & Her drawings are funny (1 pupil) \\
\hline & $\begin{array}{l}\text { No answer; the answer does not } \\
\text { refer to this character ( } 2 \text { pupils) }\end{array}$ & She is vindictive (1 pupil) \\
\hline & $\begin{array}{l}\text { She likes writing books and draw- } \\
\text { ing ( } 1 \text { pupil) }\end{array}$ & $\begin{array}{l}\text { She has eyebrows on the drawing } \\
\text { made by Vilibald ( } 1 \text { pupil) }\end{array}$ \\
\hline & She made fun of herself (1 pupil) & Her hair is dark (1 pupil) \\
\hline & She is angry and happy (1 pupil) & \\
\hline & She is a writer (1 pupil) & \\
\hline
\end{tabular}

The teachers showed the pupils several other picture-book covers and introduced them - by way of demonstration - to the art technique they were to use later, while simultaneously reviewing relevant art terms. The pupils were instructed to create a cover for their own picture book (Figure 1). Once the creative process was completed, their work was evaluated based on previously agreed criteria (different types of lines, familiar and contrasting colours, combining letters and images, composition).

\section{Figure 1}

Designing picture book covers

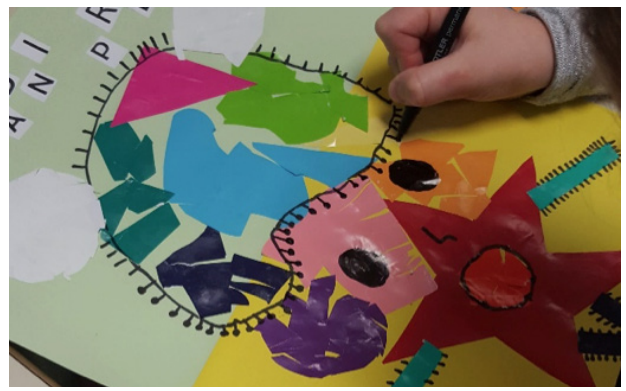


Participant observation showed that the pupils were somewhat reserved, not being used to having two teachers in class simultaneously, but within minutes, they relaxed and started to participate more actively. It should be noted that the group was rather heterogeneous with regard to their prior knowledge. The teachers spent quite some time encouraging the pupils who were less willing to cooperate, which was most evident during questioning when the same set of pupils kept volunteering to answer the questions posed. The worksheet that was provided to help the pupils describe the literary characters proved to be a very positive aid, as they were able to work individually while assisted and encouraged - as much as was needed - by the teachers.

After the first learning unit, the pupils were given another short questionnaire. There were 18 respondents. We can conclude that the majority of the pupils liked the activities and would not change them.

\section{The second unit of the interdisciplinary module}

The second unit of the module comprised four lessons. As regards the Slovenian language, the pupils identified non-verbal messages incorporated in the text (pictograms, images, etc.), became aware of the poem's sonority (relating it to the images that constitute textual reality), perceived the rhyme as a sound device, observed the relations between the rhymed words in terms of their meaning, perceived the visual imagery of the poem, understanding the relationship between the visual aspect of the text and its message, and observed the structure of the poem (i.e., the verse and the stanza first, followed by the length of the verse, and the number and the length of the stanzas). As regards art education, the pupils learned (by observing the artworks (i.e. the illustrations)) the visual art terms related to two-dimensional design (symmetry, asymmetry, familiar colours). The pupils' assignment was to use mixed media (combining collage and pencil drawing), thus developing their sense of arranging various shapes on a flat surface.

First, the pupils were presented with a questionnaire composed of three open-ended questions (What information is normally included in a picture book cover? Can you remember what you saw on the cover of the picture book Vilibald? What information is normally included in a picture book cover?). Although there were 18 respondents, we excluded two pupils who were absent from the previous learning unit, so we only analysed the responses of 16 pupils. The pupils listed the author, the title, and the illustration as the most vital information on the book cover, which means that, in their view, the illustration was equally important compared to other elements of the book cover. The ability to derive information from all communication codes equally begins when a person understands all communication codes and treats them as equal. 
In the second unit, the pupils were introduced to the picture book Zdravljica written by France Prešeren and illustrated by Damijan Stepančič (2003). While reading the poem, the pupils observed the illustration (two pupils shared one copy of the picture book). In the discussion that followed, the pupils were encouraged to inspect and describe the illustrations and discuss the arrangement of illustrated figures on each double-sided illustration (asymmetrical composition). They were then given a worksheet and were asked to fill in the gaps with the number of stanzas, verses, and the names of famous people from Slovenian history. They also had to find and write down the rhymes and associated historical characters from the illustrations. After reviewing the worksheets with the teacher, they realised that each double-sided illustration contained a different number of illustrated historical people. Their next task was to write their own verses and form stanzas. The teacher encouraged them to play with the shape of their poem like France Prešeren had done (the verses created the shape of a chalice). The book covers that they had produced in their previous lesson were also distributed to the pupils, which served as a prompt for writing verse. Once they were done with their verses, they discussed with the teacher whether they could illustrate them. The teacher demonstrated a mixed media technique (which combined gluing different pieces of paper to a surface (collage) and drawing with a soft pencil) and explained the term »harmonic colours". Next, the pupils were instructed to illustrate their verses, combining various materials and techniques, paying attention to familiar colours, expression through lines, composition, technical execution, and originality (Figure 2a, Figure 2b).

Figure 2a

Illustrating poems - work in progress

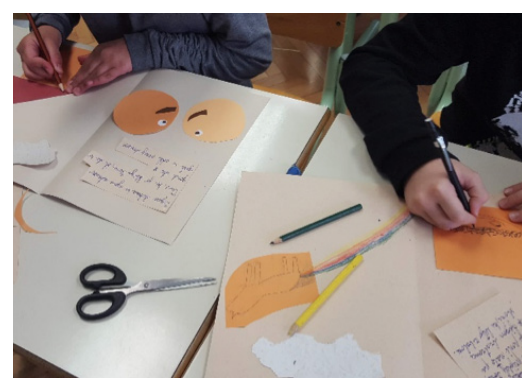

Figure 2b

A finished product

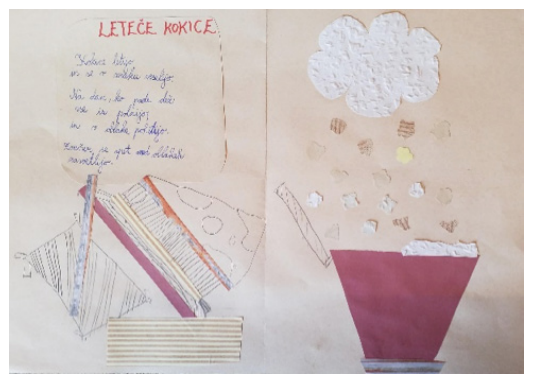

Participant observation revealed that the assignment posed a huge challenge for the pupils, particularly due to the lessons' interdisciplinary nature. The pupils dealt with the problem over a longer period and from the point of view of two school subjects. They spent quite some time pondering on what to write. 
Having their visual art product (the book cover) from the previous lesson in front of them proved very positive, as it served as an encouragement. Every one of the pupils came up with an idea. The covers also helped the teachers, as they used them to encourage the pupils by directing their attention to their artworks.

After the second learning unit, we examined the pupils' responses by means of a questionnaire, which was completed by 19 pupils (one pupil was late for class and therefore did not participate in the first questionnaire). We discovered that the majority of pupils liked artmaking and verse writing.

\section{The third unit of the interdisciplinary module}

The third unit of the interdisciplinary module comprised three lessons. With respect to the Slovenian language, the pupils identified (with the help of the teacher) the rhythm of the poem, distinguished fast and slow rhythm, perceived the rhyme as a sound device, observed the structure of the text (first with regard to the verse and the stanza), considered the emotional and imaginational richness of the poetic language, and constructed unusual phrases, based on which they composed a short text, in this case, a poem. As regards art education, the pupils learned, through artwork (illustration) observation, new terms related to two-dimensional design (rhythm, colour relations), combined various art forms (graphics, drawing), and developed their sense of arranging different shapes on a flat surface.

Initially, the pupils were given a short questionnaire. It was distributed to 21 pupils, but we analysed only 19 questionnaires, as two pupils who were not present at the last session were excluded from the survey. The first question was designed to verify whether the pupils recalled what they had observed on the cover of Zdravljica. The next question was designed to discover whether the pupils recalled any famous people from the picture book discussed. The last question was aimed at discovering what the pupils remembered best from the picture book Zdravljica. In terms of the complexity of the text and the illustrations, the picture book Zdravliica was considerably more demanding compared to the picture book Vilibald. The pupils' responses revealed that they were mostly attracted to rich illustrations, which they described as interesting and weird, recalling several specific motifs.

In the third learning unit, the pupils were instructed to examine endpapers in various picture books and classify the books based on what type of endpapers they featured (coloured or illustrated, identical or different front and back endpapers). By examining various illustrated endpapers, the pupils learned the notion of rhythm in composition, which was followed by a discussion of the rhythm in poems. The pupils read the poem Velike in male noge (»Big and little feet«) from the collection Klepetosnedke (1996) by Bina Štampe-Žmavc and 
had to find the basic poetic elements (rhyme, stanzas, and verses). Learning that rhythm can be found in poems, artworks, nature, and so on, they were encouraged to suggest the easiest way to display rhythm in an artwork. The technique of seal printing and drawing on toned paper using a felt-tip pen was then demonstrated to them (thereby revising the terms, such as »seal printing «, »rhythm «, »drawing ", and »line types«) and they were instructed to design endpapers for their picture books, focussing on rhythm, technical execution, combining stamps and drawing, and originality (Figure 3). They had to source the idea for the recurring shape on the endpaper from the product they made in the previous session (the pupils who missed the previous lesson had to invent a shape).

\section{Figure 3}

Endpaper design

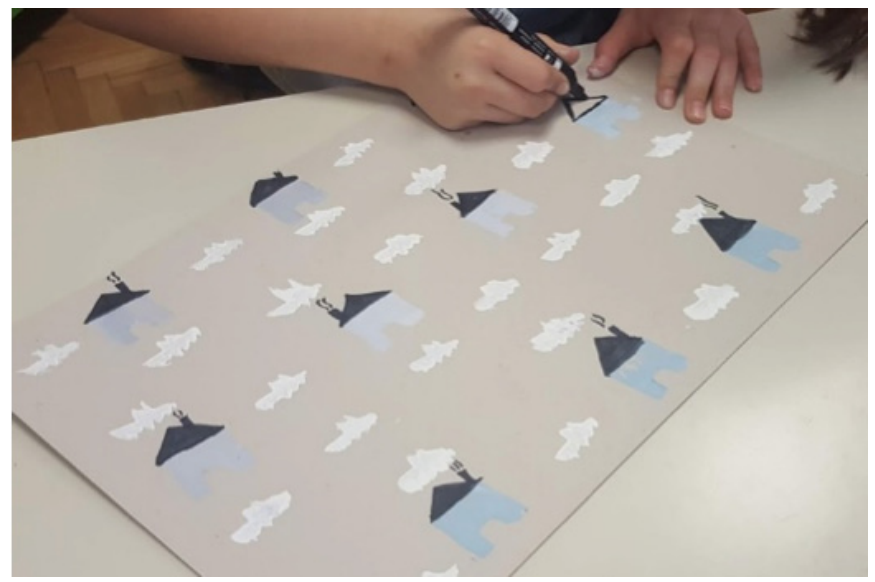

Participant observation revealed that the pupils enjoyed taking part and mostly had no problems making the endpapers. It was obvious that they had not known the term »endpaper « before and had hardly paid any attention to endpapers in the books they had read. When asked to classify various picture books based on the type of the endpaper used, they showed great interest in the illustrated endpapers, particularly when the front endpaper was different from the back one. The pupils had no difficulty applying the term »rhythm « to either visual arts or poetry. It needs to be underscored that in the creative process the pupils derived much inspiration from their previous products, which again proved extremely positive.

After the completion of this learning unit, the pupils were given a questionnaire. It was answered by 21 pupils. We discovered that the majority of pupils generally liked the activities, with seal printing being their favourite. 


\section{The fourth unit of the interdisciplinary module}

The fourth unit of the interdisciplinary module comprised four lessons. As regards the Slovenian language, the pupils had to identify (with the help of the teacher) the theme of the text and its message (tradition and heritage) and write their own texts, dividing them into paragraphs, observing orthographic rules, paying attention to the legibility and aesthetics of their handwriting, and deciding on the use of either handwritten or printed letters. Working with artworks, the pupils learned the art terms related to two-dimensional design (»familiar colours", »warm and cold colours«), combined various artforms (by producing a coloured drawing), developed their sense of arranging various shapes on a surface, and gained experience in colour mixing techniques.

Prior to the learning unit, the pupils were given a questionnaire with open-ended questions, which was answered by 19 pupils In the first question, they were asked to name the components of a picture book cover by circling the right answer among a set of possibilities: picture book title, poem, author of the text, author of the illustrations, illustration, story, and publishing house.

The next question was designed to determine what they thought was more important in a picture book. The pupils were given three possibilities: (a) the illustrations are more important than the text, (b) the illustrations and the text are equally important, and (c) the text is more important than the illustrations. In the last question, the pupils had to match word pairs (illustration-lines, colours, and shapes; text-words, sentences, various fonts; cover-title, author, illustration; and endpapers-can be only coloured or illustrated). Judging by the answers, the pupils recognised the vital elements, most of which are included in the picture book cover, as well as their visual and content-related characteristics (in a pair matching task). An interesting observation was that nearly half of the pupils thought that the illustrations were more important than the text.

At the beginning of the fourth learning unit, the pupils were asked to recall the first picture book from their childhood. They were then shown various leporellos, which are folded picture books made of cardboard, and introduced to a picture book by Andreja Peklar, Fant $z$ rdečo kapico (»The Boy with a Little Red Hood «, 2006), which is also a leporello but is not only intended for younger children. While reading the book, the pupils attempted to discover where the author found the inspiration for the story. They were then introduced to the Vače Situla and instructed to find a correlation between the historical artefact and the picture book in terms of the motifs and the forms used. After that, the pupils were given a worksheet entitled A draft for my picture book and had to write five sentences (one covering the introduction, three outlining the body of the text, and one for the ending) and draft an illustration to go with the text. We used an example from 
the picture book to explain the relationship between the text and the illustration in terms of the content (a piece of information that is included both in the text and the illustration vs a piece of information that appears in the illustration but is not mentioned in the text). After the pupils finished the draft of their picture book, we discussed how they could produce an actual picture book. The teacher demonstrated how to draw with a black felt-tip pen and fill the spaces created with colours (using crayons). During the demonstration of various expressive possibilities, the pupils and the teacher discussed warm/cold colours and familiar colours. The pupils produced their own leporello, paying attention to line as the basic tool for artists, along with warm and cold colours, familiar colours, colour mixing, composition, and originality (Figure 4).

\section{Figure 4}

Picture book design (leporello)

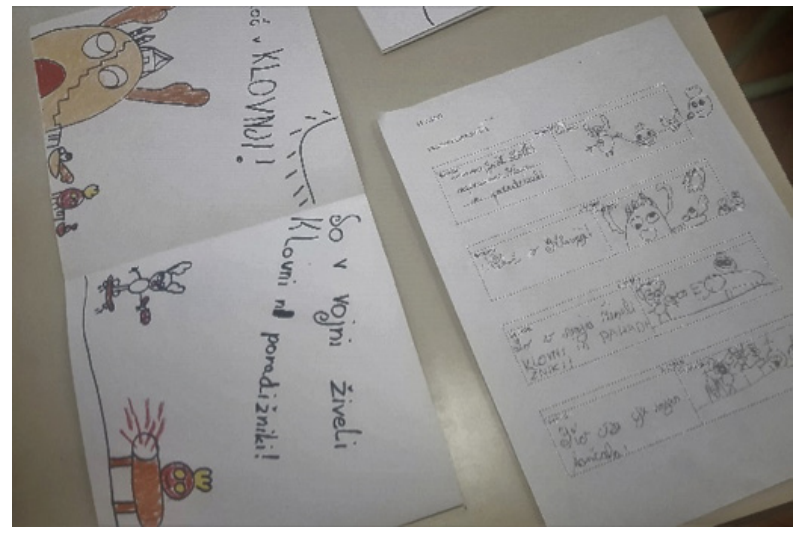

Participant observation showed that the pupils approached the set tasks with considerable confidence and certainty during the last session. In earlier sessions, it was noticeable that they found dealing with one problem from two different perspectives rather demanding over a long period. In the last session, however, the pupils seemed very relaxed and hardly uncertain in the assignments they were given (writing, creating a draft of a picture book, and the final making of a picture book). In the design process, the pupils focussed on both texts and images: specifically, the messages conveyed through the words and illustrations. Participant observation revealed that they were very successful and understood that certain pieces of information could appear twice, while others only appeared either in the text or in the illustrations. As regards the format, half of the pupils designed their picture books so that the text and the 
illustrations appeared as two separate elements (Figures $5 \mathrm{a}$ and $5 \mathrm{~b}$ ), while the other half of the pupils merged the two to create a whole (Figures $6 \mathrm{a}$ and $6 \mathrm{~b}$ ).

\section{Figures $5 a$ and $5 b$}

A. K., Neuničljiva ladja (Indestructible ship)
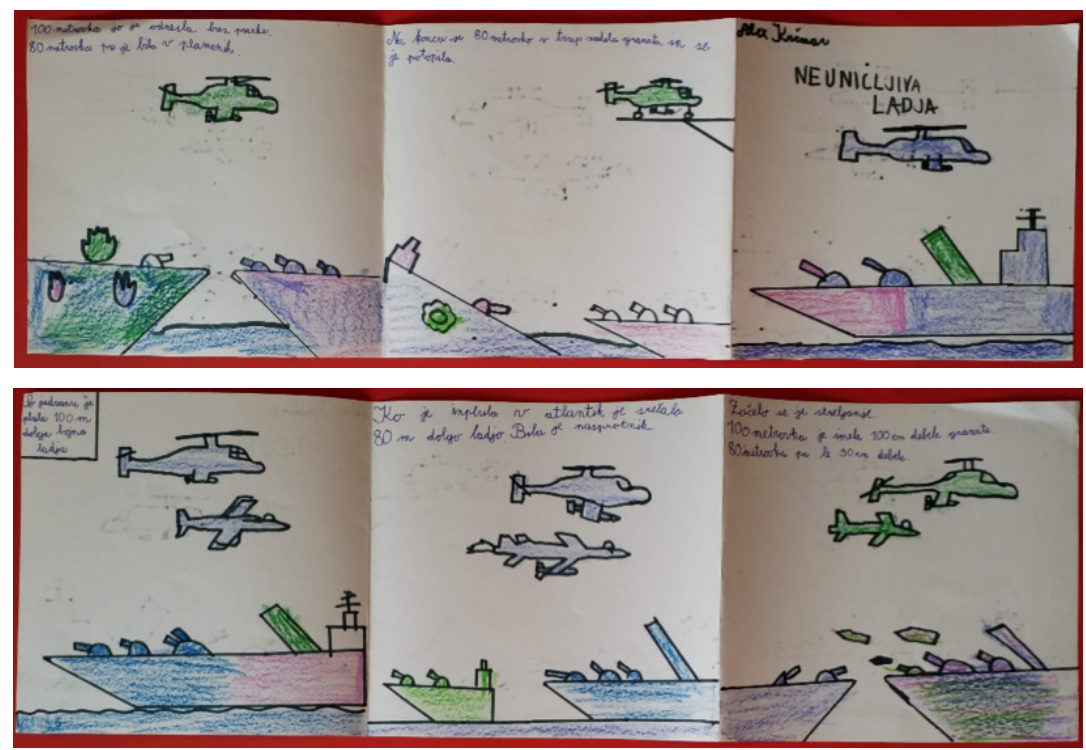

Figures 6a and 6b:

N. B., Jež se izgubi v svojem gozdu (Hedgehog gets lost in its forest)
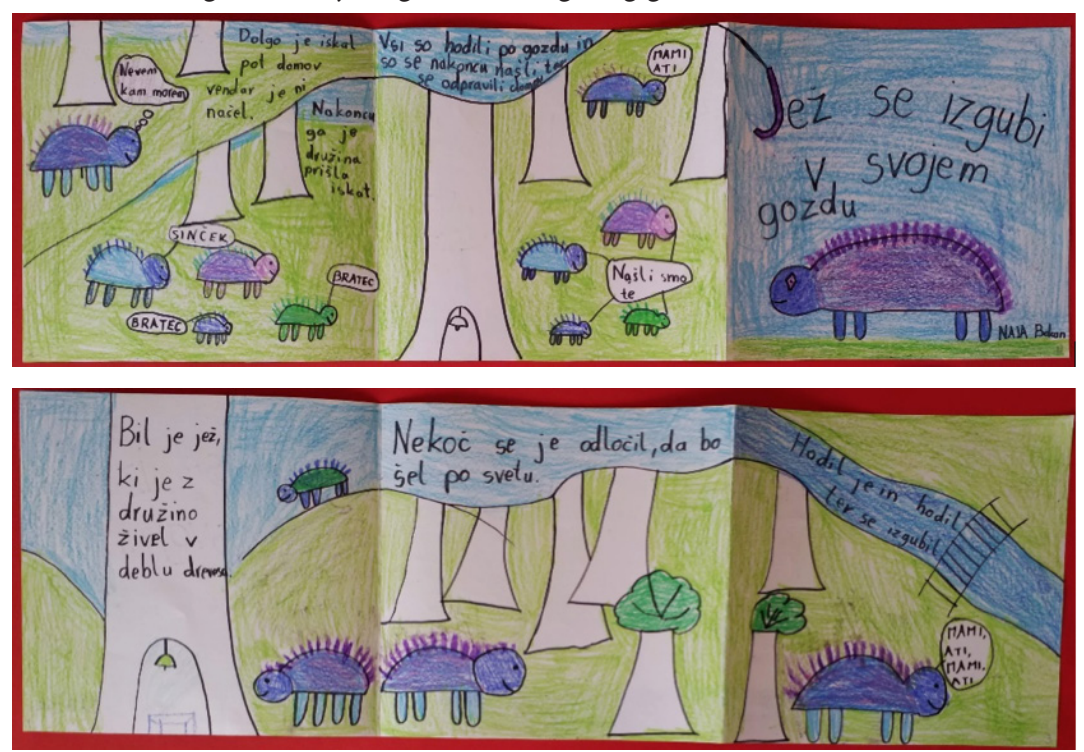
After the fourth learning unit, the pupils were again given a questionnaire designed to examine their opinions of the entire interdisciplinary module. We analysed the questionnaires of 16 pupils who were present during all four units. Everyone agreed that they liked working with picture books.

Furthermore, we asked the pupils how much they liked individual activities, offering several possible answers: I did not like it, I somewhat liked it, I liked it, and I liked it a lot (Table 2).

Table 2

How did you like individual activities?

\begin{tabular}{|c|c|c|c|c|c|c|c|c|c|c|}
\hline \multirow[t]{2}{*}{ Activities/Answers } & \multicolumn{2}{|c|}{$\begin{array}{l}\text { I did not } \\
\text { like it }\end{array}$} & \multicolumn{2}{|c|}{$\begin{array}{l}\text { I some- } \\
\text { what } \\
\text { liked it }\end{array}$} & \multicolumn{2}{|c|}{ I liked it } & \multicolumn{2}{|c|}{$\begin{array}{c}\text { I liked it } \\
\text { a lot }\end{array}$} & \multicolumn{2}{|c|}{ Total } \\
\hline & $f$ & $f \%$ & $f$ & $f \%$ & $f$ & $f \%$ & $f$ & $f \%$ & $f$ & $f \%$ \\
\hline Reading picture books & 1 & 6.3 & 1 & 6.3 & 3 & 18.7 & 11 & 68.7 & 16 & 100 \\
\hline $\begin{array}{l}\text { Designing one's own picture } \\
\text { book cover (collage) }\end{array}$ & 0 & .0 & 0 & .0 & 3 & 18.7 & 13 & 81.3 & 16 & 100 \\
\hline Writing poems & 1 & 6.3 & 1 & 6.3 & 2 & 12.5 & 12 & 75.0 & 16 & 100 \\
\hline $\begin{array}{l}\text { Illustrating one's own poem } \\
\text { (collage, pencil drawing, making } \\
\text { rubbings', etc.) }\end{array}$ & 0 & .0 & 3 & 18.7 & 1 & 6.3 & 12 & 75.0 & 16 & 100 \\
\hline $\begin{array}{l}\text { Endpaper designing (potato } \\
\text { stamping and felt-tip pen } \\
\text { drawing) }\end{array}$ & 2 & 12.5 & 2 & 12.5 & 3 & 18.7 & 9 & 56.3 & 16 & 100 \\
\hline $\begin{array}{l}\text { Making one's own picture book } \\
\text { (writing the story and making } \\
\text { the illustrations) }\end{array}$ & 0 & .0 & 0 & .0 & 3 & 18.7 & 13 & 81.3 & 16 & 100 \\
\hline
\end{tabular}

The last question was open-ended and allowed the pupils to share anything else related to their work or leave a message for the teachers. Their responses were grouped into categories. The first group comprised eight pupils who liked the work and had fun. The second group comprised five pupils who expressed their hopes that something similar would be repeated. One pupil wished that the reading and the explanations would not have taken as much time as they had, one disliked the questionnaires, and one did not write anything.

\section{The results of testing the effects of our case study}

The survey involved 18 out of 21 pupils and examined their ability to decode the message of a multimodal ensemble, which was conducted prior to the interdisciplinary module. The same number of pupils participated in the survey after the completion of the interdisciplinary module. We analysed the 
responses of the pupils that were present for both surveys $(n=16)$.

\section{Decoding the message from illustrations prior to the interdisciplinary module delivery}

The responses clearly showed that 12 pupils wrote down what they saw in the central illustration on the cover.

Five of the 12 pupils described only the central illustration. Their responses can be divided into those that provided detailed descriptions (three pupils) and those whose descriptions were rather brief (two pupils). Four pupils provided other details along with a description of the central illustration, three of them mentioning the motifs located on the far-left side of the cover page.

The responses of three pupils, however, included their interpretation of the central illustration.

\section{Decoding the message from the text prior to the interdisciplinary module delivery}

Only five pupils used the information from the text in their answers. Four pupils mentioned the word »comics«. Three pupils mentioned »Slovenian fairy tales and a German one« (this was obvious from the title). Two pupils mentioned the title; one only as a term, with the other citing a part of the title (»Slovenian Fairy Tales in Comics«). Two pupils mentioned the publishing house, and two recalled the reference to the author.

\section{Decoding the message from illustrations after the interdisciplinary module delivery}

After the delivery of the interdisciplinary module, 10 pupils described the illustration, of which five mentioned the motifs both in the central illustration and the side illustrations. Two pupils shared their interpretations of the central image.

Three pupils mentioned the illustrations, but either did not describe them or just made a brief reference to the story they recognised from the illustration.

\section{Decoding the message from the text after interdisciplinary module delivery}

Ten pupils mentioned the publishing house and seven pupils mentioned the title (either mentioning the term or writing down the actual title). Six pupils noted that the book included Slovenian fairy tales, while two of them mentioned that one fairy tale was German. The author was mentioned (either 
referring to the term author/illustrator or to the actual names) by six pupils. The same number of pupils mentioned the word comics.

\section{Survey findings}

The objective of our survey was to discover pupils' viewpoints regarding an interdisciplinary module. Based on the analysis of their responses and participant observation, we established that the pupils were generally enthusiastic about this particular learning method with and about picture books, even if it was entirely new to them. They had little prior knowledge, and the majority thought a picture book was a book with many pictures. When asked about the most recent picture book they had read, over half of the pupils provided no answer. We noticed that the pupils were predictably more reserved at the beginning of the module but became more active and motivated with each successive session. In the beginning, focussing so much time (i.e., three lessons) on a single problem through different tasks was rather unusual to them. It turned out that the tasks were adequately demanding and interesting for most pupils. Some issues appeared with the pupils who otherwise have difficulties composing text. For the pupils that came from a different speaking environment, Slovenian was not their mother language, while two of the pupils had speech and hearing impairments. Due to concentration issues, some pupils required additional guidance and encouragement to finish their writing and/or art assignments. The pupils were given a questionnaire before each interdisciplinary module. Their answers showed that individual picture books discussed were not retained their minds (specific illustrations, motifs). At the same time, it was made clear that they still had significant issues recognising the components of a multimodal ensemble (e.g., a picture book cover) even after three units had been completed. At the end of the module, the pupils exhibited positive attitudes towards an interdisciplinary approach to picture book discussion.

We were also interested in how the pupils felt about specific activities within the interdisciplinary module. The results we obtained through the questionnaires showed that the pupils generally liked various activities. In the first learning unit, they were fond of reading the picture book and designing their own picture book cover. In the second learning unit, the pupils generally preferred artmaking and writing activities, with their suggestions for improvement referring exclusively to their work. In the third learning unit, the majority found seal printing to be their favourite activity. The individual activities that the pupils found the most enjoyable were designing book covers and making their picture books. Based on the results derived from the questionnaire and 
participant observation, the pupils most frequently favoured artmaking and liked writing verses (poems), whereas they never mentioned working with worksheets. The results are hardly surprising, given that the pupils were allowed creative freedom in artmaking, the design of their picture books, and the writing of poems while being encouraged to find their own solutions. Worksheets, in contrast, focussed on detailed observation, writing down comments, and decoding messages from the text.

We observed a switch in the approach of the pupils to comprehending the messages contained in a multimodal ensemble before and after the delivery of the interdisciplinary module. After the module, the pupils could better decode the message from the text. Before the delivery of the interdisciplinary module, the responses to the questions regarding the messages conveyed by the book cover included mostly the motifs that the pupils saw in the central image of the cover. As regards the messages conveyed by the text on the picture book cover, they were summed up in a few words mentioned by only five out of 16 respondents. After the delivery of the interdisciplinary module, the approach to decoding illustrations remained more or less the same, though the descriptions of the illustrations became somewhat detailed and longer. Decoding of the messages from the text, however, changed to a greater extent, as 12 out of 16 respondents included the information contained in the text in the picture book cover (author, title, publishing house, title summary, comics, etc.). We believe that this helped them understand the overall message of the multimodal ensemble much better. Our experience with adult readers has shown that while adults generally perceive book images passively, focussing more on the text, the situation with the pupils in our case was just the opposite. Prior to the delivery of our interdisciplinary module, the pupils did not pay particular attention to the text on the book cover and tried to express the message by listing images. After the interdisciplinary module, however, they also paid more attention to the text.

\section{Conclusion}

In our research, we addressed the literary and visual part of the picture book equally. In the field of picture book research, it can be observed that the focus is mainly on the text and on the conversation about the illustrations, but without the inclusion of visual elements of art and design (Baird et al., 2016). However, picture books are an important resource for developing visual literacy, multimodal literacy, visual aesthetic understanding and visual aesthetic development (Bukovec \& Potočnik, 2019; Pantaleo, 2012; Serafini, 2014; Sipe, 2008). Doonan (1993, p. 8) notes, at some point in a child's development, a 
spontaneous response to a picture book is not enough and »knowledge is needed «. Furthermore, when pupils »have been told and shown how lines and shapes and colours are able to refer to ideas and feelings, they can explore the dimension beyond what is literally represented «(Doonan, 1993, p. 8).

Throughout the design, delivery, and evaluation of the interdisciplinary module, we focussed on the advantages and the disadvantages of an interdisciplinary model of discussing picture books as multimodal texts. The advantage revealed itself through a holistic and interdisciplinary approach to the picture book, which allowed the pupils to deal with a single problem for a longer period, focussing on two different aspects of it. Pupils need enough time to explore the illustrations, as Serafini (2011, p. 343) notes, »cognitive strategies that focus on comprehending written texts will not be sufficient to help readers comprehend the various modes of representation incorporated in multimodal texts."

However, limiting ourselves to only two fields proved to be a disadvantage as regards interdisciplinarity, as we realised rather early into the planning process that we could have included several other subjects (social sciences history, music - poem/song, natural sciences - dyes, mathematics - measurement units, etc.). The advantage of our delivery was the generalist teacher and the art teacher collaborating on lesson planning and delivery. In practice, such an interdisciplinary lesson in the fifth grade would be delivered by a generalist teacher alone, on condition that they had a sufficient level of visual and multimodal literacy. Our multimodal text discussion model might become a problem in higher grades of primary school, as this type of class would have to be delivered simultaneously by two teachers of different profiles (e.g., a teacher of Slovenian and an art teacher). Potočnik and Devetak note (2018, p. 126): »Works of fine art could be a great tool for interdisciplinary approaches [...] so cooperation between teachers is necessary."

It should be underscored that the results of our survey should by no means be generalised. However, the findings will help us with further study of the field of developing multimodal literacy by means of cross-curricular teaching.

\section{Acknowledgement}

Janja Batič wrote the paper as part of the project OBJEM: Reading Literacy and Development of Slovenian Language (Awareness, Reading, Language, Evaluation, Models), project code OP20.01462, head dr. Sandra Mršnik. The project is led by the National Education Institute Slovenia. The investment is co-financed by the Republic of Slovenia and the European Union from the European Social Fund. 


\section{References}

Baird, A., Laugharne, J., Maagerø, E., \& Tønnessen, E. S. (2016). Child readers and the worlds of the picture book. Children s Literature in Education, 47(1), 1-17.

http://dx.doi.org.ezproxy.lib.ukm.si/10.1007/s10583-015-9244-4

Batič, J. (2017). Likovno didaktične razsežnosti slikanice pri pouku likovne umetnosti [Fine art didactic dimensions of picture books in teaching art classes]. Didakta, 193, 19-24.

Batič, J. (2019). Reading picture books in preschool and lower grades of primary school. Center for Educational Policy Studies Journal. https://doi.org/10.26529/cepsj.554.

Batič, J., \&Haramija, D. (2015). The importance of visual reading for the interpretation of a literary text. Center for Educational Policy Studies Journal, 5(4), 31-50.

Bukovec, A., \& Potočnik, R. (2019). Elementary school student's attitudes on teaching artist' monochrome picture book without text and graphite technique. Teaching Artist Journal, 17(3-4),

86-102. https://doi.org/10.108o/15411796.2019.1680230

Cappello, M., Wiseman, A. M., \& Turner, J. D. (2019). Framing equitable classroom practices: Potentials of critical multimodal literacy research. Literacy research: Theory, method, and practice, 8(1), 205-225. http://dx.doi.org.ezproxy.lib.ukm.si/10.1177/2381336919870274

Doonan, J. (1993). Looking at pictures in picture books. The Thimble Press.

Eilam, B. (2012). Teaching, learning, and visual literacy: The dual role of visual representation.

Cambridge University Press.

Haramija, D., \& Batič, J. (2013). Poetika slikanice [Picture book poetics]. Franc-Franc.

Jewitt, C. (2008). Multimodality and literacy in school classrooms. Review of Research in Education, 32, 241-267. https://journals.sagepub.com/doi/pdf/10.3102/0091732X07310586

Mesec, B. (1998). Uvod $v$ kvalitativno razsikvanje $v$ socialnem delu [An introduction to qualitative research in social work]. Visoka šola za socialno delo UL.

Pantaleo, S. (2012). Exploring grade 7 students' responses to Shaun Tan's the red tree.

Children's Literature in Education, 43, 51-71. https://doi.org/10.1007/s10583-011-9156-x

Pavlič Škerjanc, K. (2010). Smisel in sistem kurikularnih povezav. Medpredmetne in kurikularne povezave, Priročnik za učitelje [Sense and system of curricular integration. Interdisciplinary and cross-curricular integration, teachers' manual]. Zavod RS za šolstvo.

Potočnik, R., \& Devetak, I. (2018). The differences between pre-service chemistry, fine art, and primary education teachers regarding interest and knowledge about fine art materials. Center for Educational Policy Studies Journal, 8(4), 109-130. https://doi.org/10.26529/cepsj.352

Sagadin, J. (1991). Študija primera [Case study]. Sodobna pedagogika, 42(9/10), 465-472.

Serafini, F. (2014). Reading the visual: An introduction to teaching multimodal literacy. Teachers

College Press.

Serafini, F. (2011). Expanding perspectives for comprehending visual images in multimodal texts.

Journal of Adolescent \& Adult Literacy, 54(5), 342-350. https://doi.org/10.1598/JAAL.54.5.4 
Sipe, L. R. (2008). Learning from illustrations in picture-books. In N. Frey \& D. Fisher (Eds.), Teaching visual literacy: using comic books, graphic novels, anime, cartoons, and more to develop comprehension and thinking skills (pp. 131-148). Corwin Press.

Vogrinc, J. (2008). The importance of triangulation for ensuring the quality of scientific findings of the qualitative research. Contemporary pedagogy, 59(5), 110-124. https://www.dlib.si/stream/ URN:NBN:SI:doc-KH1Q1Q5I/36ecf4e3-12f1-4edd-9aac-106af6636c5f/PDF Yenawine, P. (2013). Visual thinking strategies. Harvard Education Press. Yi, Y., \& Choi, J. (2015). Teachers' views of multimodal practices in K-12 classrooms: Voices from teachers in the United States. TESOL Quarterly, 49(4), 838-847. https://www.jstor.org/stable/43893789

\section{Biographical note}

JANJA BATIČ, PhD, is an assistant professor for art education at the Faculty of Education (Department of Fine Arts) at the University of Maribor, Slovenia. Her research interests are art education, art education as subject-specific education, teacher training, picture book illustration and phenomenon of comprehensive reading of picture books as multimodal texts.

Petra Lebar Kac, M. Sc., is a primary school teacher in fifth grade, in the Primary school Janka Padežnika Maribor. Her research interests include early science education, children with migrant background, inclusive education, interdisciplinary approach in teaching. 